\title{
The phenomenon of social risk families and its dynamics in Lithuania
}

\author{
Vide Gudzinskiene and Rimvydas Augutavicius \\ Mykolas Romeris university, Lithuania
}

\begin{abstract}
Families at risk are definitely the urgent public concern that requires immediate solutions in Lithuania. It is important to mention that the children growing within the families at risk are in the centre of concern as their social and physical environment is not stimulating enough, leading to a number of different problems the families and children themselves are facing. In general, the number of such children makes about 4 percent of the total number of children in the country and this rate has remained stable for many years. Scientific problem - the problems experienced by children growing within social risk families and the impact of social risk factors on children's socialization and integration. Object - phenomenon of families at risk in Lithuania. Task of the article - to analyze the phenomenon of social risk families and its trends in Lithuania.
\end{abstract}

Key words: social risk families, children, social and physical environment, socialization and integration.

\section{Introduction}

In the recent years, families at social risk usually live on state-funded benefits (there were 221922 social welfare recipients in 2012) [1]. These families often add some extra income by illegal means (smuggling, unofficial work), however majority of them do not work at all, and claiming the reason for their unemployment is the low wage paid in the market. According to the official statistics the poverty rate among citizens over 18 years old were mainly distributed among the unemployed people $(53.1 \%)$, inactive ones (29.1\%), elderly pensioners $(14.8 \%)$, employed people (10.1\%) [2].

According to the data provided by the Lithuanian Department of Statistics, within the recent years, the birth rate in Lithuania has decreased by 3.6 percent. This has indirectly led to the decrease of social risk families and children respectively by 8.5 and 16.4 percent. Currently, the largest population of social risk families is in Kaunas, Vilnius, Klaipeda and other districts.

The exploration of the topic: Social Risk phenomenon in Lithuania has been viewed by many scientists: some of the authors [3] studied the social situation of families at risk and analyzed emerging of new factors that affected the expression of social tensions; others [4] analyzed the phenomenon of social exclusion in the Lithuanian society, they also dealt with the areas in which this concept could be applied in analyzing the various social groups, social exclusion and integration opportunities in the target group. The role of the family in the process of child socialization, parents' education problem in this respect was also in the focus of research [5]. Some studies in Lithuania focused on children growing in families affected by alcohol misuse problems, who experienced the psychological, social and learning difficulties [6], social skills peculiarities [7] and the specifics of the behaviour of juveniles sentenced to imprisonment in their home and lifestyles [8]. 
The objectives of this article:

1) to define the concept of social risk families;

2) to describe the reasons of the families' assignment to the register of families at risk;

3) to disclose the trends and dynamics of the target group population in Lithuania.

Methods used to study the problem: the generalization and synthesis of relevant scientific literature and legislation.

\section{Study of social risk families}

\subsection{The concept of social risk families}

A number of various concepts and definitions exist in different countries to define what we can call the family at risk or social risk family. These concepts are greatly influenced by the cultural and political traditions of the country, perceptions of social risk as phenomenon and other aspects of society. Definitely, we need to look and explore the definition of social risk family by discussing the essential characteristics of these families. Some authors emphasise that the key role in the development of the child's personality is played by the family, because the social roles, important knowledge and skills necessary for the child's adaptation and integration in society are acquired in the family [8].

According to many authors, the family is also responsible for development of the child's sense of self consciousness, self-confidence and is crucial in developing creative potential and social activity. Unfortunately, not all the families are able to perform their role in the appropriate level, even though the society has set the social norms and responsibilities as well as liability limits that define how successful the family is; moreover, these norms can provide the background and framework for judging and defining the risks that put the families to the position of becoming socially [8]. The authors in Lithuania call such disadvantaged families - the social risk families or families at risk because of their marginalized profile.

Social risk family concept in the scientific and professional literature is interpreted slightly differently. The legal documents of the Republic of Lithuania regulating social security and welfare put emphasis on these families [9-13]. Some of the legal documents focused on negative parental behaviour characteristics and patterns while others-on the negative consequences of parental behaviour (misbehaviour) on children living in such families. The content analysis of these documents enabled the authors to extract the main categories, which would define the concept of the families at risk [14].

In general, the social risk family may be defined as a family upbringing children under 18 years of age and wherein at least one of their parents is characterized by one or several risk factors: abuse of alcohol, narcotics, psychotropic or toxic substances; is addicted to gambling; due to lack of social skills is/are unable or not motivated to provide the appropriate care to their children; the psychological, physical or sexual abuse might be used; the financial state support is not used for family needs, and due to these factors there is a risk to the child's physical, mental, spiritual, moral development and safety. The foster care family under the regulations of temporal care legislation would also be counted as social risk [10].

Social risk family can also be characterized by disorganized cooperation and emotional communication, negative environment that do not promote a healthy, productive personal growth and development. Due to the negative impact on the wellbeing of the adults and their negative behavioural habits it is not likely that the emotional and physical needs of the children can be met. On the other hand, the patterns of communication in these families greatly limit the child's ability to express their needs and feelings adequately. Another 
important factor is the legal recognition and inclusion of such families into the State register of social risk families. This means that every municipality in Lithuania would include the family into the register, once the initial assessment has been carried out under the procedures of "recommendations for work with social risk families" and the information collected led to the identification of risk factors. The signal of a child at risk can be received from any external or internal source (neighbours, family, school, kindergarten, medical practice, police, etc) and the decision to include the family into the register is made by local authority $[9,10]$.

According to the provision of Child Benefits Act as well as Cash social assistance to low-income families and (or) (Single Persons) Act (1993) Social services Act (2006) social risk family is defined as follows: it is the family, characterized by the prevailing crisis due to reasons such as abuse of alcohol, narcotic, psychotropic, toxic substances, or (and) the dependence on gambling, or (and) because of a disability, poverty, lack of social skills or failure to provide care for their children, or (and) the use of psychological, physical or sexual abuse, or (and) assistance received from the State is used for purposes other than the family's interests. These factors result in risk to the child's physical, mental, spiritual and moral development, as well as security [16-19].

Social risk family as a social institution and as a type of small primary social group does not comply with the characteristics of the purpose of the family, while the misinterpretation of its functions expose them to negative social factors, posing a risk of social problems to normal functioning of society $[6,8]$.

Social risk family is also described as a family whose social functioning is disturbed due to some objective or subjective reasons: this may be refugee families, large families, families raising children with disabilities, single-parent families. It is also likely that real social risks may occur under adverse economic and psychological conditions or might be triggered by rising problems of child upbringing, conflicting families, alcohol abuse, use of drugs, and the use of violence in the family [20].

Researches, identifying some categories, which characterized the main consequences to children of inappropriate parental behaviour within disadvantaged families: inability or lack of physical, mental, spiritual and moral development, and security provision; created family environment is not stimulating healthy and productive growth and development of children; ill communication and cooperation between members of the family limit children's ability to express their needs and feelings; children have unfavourable self-esteem; children have not acquired the necessary social skills; the fundamental rights of children are not realized (care, education, etc.); the opportunities of children to participate in social life of society, spiritual growth and development are restricted [6-8, 19].

Concluding on the concept of social risk family it can be said that these families are characterized by the negative behaviour patterns of the parents or economic, social factors that lead to dysfunctional performance of socially assigned roles and functions. Children growing within such families would always feel inadequate or negative consequences of their parents' behaviour, which leads to a lack of child socialization and inadequate development. Due to these reasons the needs of the children are not being met, or are met insufficiently, these children are often exposed to a variety of social, physical, and psychological problems. It is clear that due to these problems the disadvantaged families with children require special attention and support, its efficiency depends largely on the identification of the causes for social risk factors to emerge.

\subsection{The causes and factors for referring to social risk family}

While analyzing the characteristics of social risk families, it is important to clarify the most common causes for this social phenomenon to emerge and possible ways to reduce 
them. The family at social risk is usually determined by a number of interrelated factors: addictions; lack of motivation to address the issues; lack of parental social skills; absence of child education; children's school attendance; adequate living conditions for children will not be ensured; psychological, physical, sexual violence; long-term unemployment; financial difficulties; health and psychological problems; difficult social adaptation after mental illness. Moreover, many of these families live in extremely poor conditions. The difficult financial situation raises tension among family members, has an impact on the psychological climate in the family, leads to the substance misuse as the way to cope with difficult reality [9].

Socio-cultural, economic and educational crisis exists within social risk families while development issues and disorders of children can be result both of the objective situation in the society and subjective and individual approach of the families to the crisis situation. According to the authors, children become socially more vulnerable because of unsecured socio-cultural environment, lack of positive relationship between the family members, neglect, misuse or negative behaviour. Because of these reasons children would form behavioural, emotional, as well as education and communication problems with peers $[6,8]$. Children lack the social skills and they often feel lonely, emotionally more vulnerable. In addition, it has also been argued by researchers that social risk families face extreme difficulties in upbringing teenage children, as this stage of human development process is the most challenging [19]. In addition to experiencing stress, he or she often suffers from many other stressful situations. However, some of the scientists believe that child poverty is not directly linked with negative performance of the children [3, 6, 8]. The most important factors that affect children are environmental rather than biological. Children of social risk families would face poverty, primitive value orientation, negative psychological climate, parenting mistakes, which could greatly influence child's personality to become dysfunctional. Living in such conditions and experiencing many social risk factors children develop low selfesteem and distrust to the world around them - leaving the children pushing themselves from the positive social environment. It is important to emphasize that learning from social environment can result in negative pattern of behaviour of children in the future [8].

Obviously, we can categorize the risk factors that lead to becoming a social risk family as follows:

1. Structure of the family (incomplete, poor families, families with disabled persons in need of constant care; family whose member(s) is/are imprisoned or had just returned from prison and going through the reintegration into society process, members belong to various marginalised groups);

2. Distorted nature of relationship within the family (lack of common interests, mutual distrust, as well as lack of mutual understanding and support among family members, emotional frigidity and rough communication).

As some of authors emphasize, disadvantaged family can be affected by categories of social risk factors at the same time. According to data from the interview taken from chief manager of Children and Youth Division of Ministry of Social Security and Labour - the family is included into the register of social risk families for the following typical reasons: parents abuse alcohol, do not use the support received for the best interests of the children and family, but rather in order to gain personal advantages, often use violence against their children, who are almost always minor - parents do not perform their social role and, accordingly do not provide the opportunities to carry out their social roles within the family for children; in terms of social welfare guarantees ensured by the state for those families of social risk, it is usually confined with financial assistance and performing some control on its use [19]. It is important to emphasize that the situation in urban and rural areas differs - more organizations providing 
social services (consulting, training, etc.) to disadvantaged families and their children operate in cities and towns. Thus, the providers of social services often have to perform social roles of parents or guardians. Meanwhile, the families inhabiting rural areas have very little or no access to these services. The abuse of social welfare benefits and state support often is one of the key reasons why the family is included into the register of social risk families.

Discussing the characteristics of social risk families in Lithuania it is often the extreme poverty conditions within which family lives [4]. Moreover, children who live at higher (relatively) socio-demographic risk conditions are more likely to experience negative emotional and behavioural problems and learning difficulties in school in comparison with peers who do not live in such conditions. Such children often get worse grades in school, are less likely to commit themselves, etc. Risk children are characterized by two essential elements-the behaviour of these children differs from the accepted norms of society, and for this reason, they are under constant crisis. It has also been identified that the tendency of delinquency is higher among the children from social risk families. The data from the research [22] has disclosed that economic, demographical, moral and other risk factors that can be described as social tensions, also link with socio-cultural status (background), poor education of the parents, limited possibilities to employment.

Socio-demographic risk factors may be grouped as follows: single parents; four or more children live in the family that lately has been included into social risk family's register; low level of education of parents and poverty [3].

Researchers have identified the following major problems that social risk families might face as well as possible solutions to these problems:

- some of the problems could be solved by increasing the role of social work in local administrative authorities (municipalities), so it is important to strengthen the capacities of the social workers working directly with children and families within elderships;

- more social work vacancies needed to be established in elderships as this could result in improved quality of services provided to social risk families. Early prevention can help to avoid complex situations in the future;

- intense social work can help to reduce the numbers of social risk families in the official register as it would be expected that more social risk families could be socially rehabilitated. This, of course, would also minimise the negative impact of social risk factors on children wellbeing and encourage development of positive self concept and self-esteem of the children, promote the rights of the children and strengthen the capacities of their parents to provide a proper care and improve family relationships thus creating the right conditions for children to grow in their biological family.

Positive changes can only be expected if an adequate adjustment of the legal framework, regulating the provision of social services to social risk families, is initiated $[3,6,8,19]$.

In general, distinguishing a family as of social risk can be determined by various social, economic and cultural factors. Often these factors are inter-related, affect one another and overall wellbeing of the family and might lead to the emergence of new negative factors. Poverty, alcoholism, drugs or psychotropic substance abuse, violence, depression, discrimination in the family and in society, children absent from school, running from home, involvement in criminal and antisocial activities result in including families to the official state register of social risk families.

\subsection{The trends of social risk phenomenon in Lithuania}

The social problems existing within social risk families have got the negative impact on the socialization and integration of children, especially in the social environment: schools and 


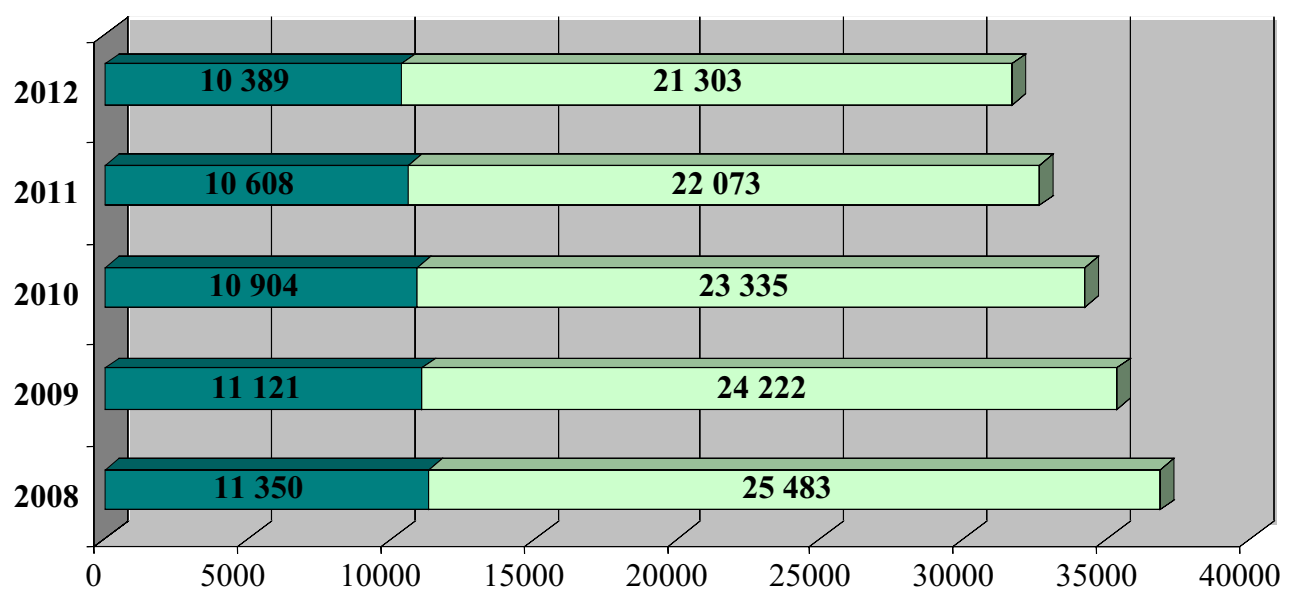

The number of social risk families

The number of children in social risk families

Fig. 1. The number of social risk families and children growing in these families in 2008-2012. Source: Statistics of Lithuania, internet access: http://db1.stat.gov.lt/statbank/default. asp? $\mathrm{w}=1280$.

Table 1. The distribution of social risk families in 2008-2012.

\begin{tabular}{|l|l|l|l|l|l|}
\cline { 2 - 6 } \multicolumn{1}{c|}{} & $\mathbf{2 0 0 8}$ & $\mathbf{2 0 0 9}$ & $\mathbf{2 0 1 0}$ & $\mathbf{2 0 1 1}$ & $\mathbf{2 0 1 2}$ \\
\hline Total number of families & $\mathbf{1 1 3 5 0}$ & $\mathbf{1 1 ~ 1 2 1}$ & $\mathbf{1 0 9 0 4}$ & $\mathbf{1 0} 608$ & $\mathbf{1 0 3 8 9}$ \\
\hline Urban area & 4110 & 4291 & 4303 & 4252 & 4207 \\
\hline Rural area & 7240 & 6830 & 6601 & 6356 & 6182 \\
\hline
\end{tabular}

peers. Negative risk factors also affect the moral values, interests and development of physical and mental health. Therefore, it is necessary to discuss the volumes of the phenomenon of social risk and direction of problems that result in the inclusion of certain families in the register of social risk families and limit the possibilities for the children to meet their needs.

According to the data of Statistics of Lithuania for period of 2008-2012, the number of social risk families in Lithuania has decreased by 8.5 percent, in the period of 5 years, while the number of children growing in social risk families - respectively by 16.4 percent (Fig. 1). However, this trend can be attributed to a decline in birth rate and migration tendencies the Statistics of Lithuania data shows that the birth rate in Lithuania has decreased by 3.6 percent. During the period of 2008-2012; while the emigration dynamics in the group of children under 17 years of age has doubled during the period analysed. The fact of decreasing number of children in social risk families is also confirmed by other data for the same 2008-2012 period [22-25]. The ratio of children in social risk families in respect to total population of children in the country has remained stable and was 4 percent.

The vast majority (almost 70 percent) of social risk families in Lithuania live in rural areas (Table 1). It is important to note that in the period of 2011-2012 the number of social risk families in urban areas changed insignificantly, while the number of these families decreased by 2.7 percent in rural areas [1, 22, 25-27].

The most common reason for including the families into the register of social risk families in Lithuania was for parents' drinking, misuse of psychotropic substances, as well as the lack of parenting skills (Table 2). Respectively - the majority of the children from social risk families grew in these families. 
Table 2. The distribution of characteristics of social risk families and children in 2008-2012 by causes.

\begin{tabular}{|c|c|c|c|c|c|}
\hline & 2008 & 2009 & 2010 & 2011 & 2012 \\
\hline Total number of families & 11350 & 11121 & 10904 & 10608 & 10389 \\
\hline \multicolumn{6}{|l|}{ From this number due to: } \\
\hline Parents' abuse of alcohol and other substances & 6697 & 6245 & 5896 & 5439 & 5072 \\
\hline Lack of parental skills & 3527 & 3661 & 3746 & 3890 & 3985 \\
\hline Establishment of temporary care for children & 180 & 220 & 282 & 289 & 358 \\
\hline Abuse of social welfare benefits & 80 & 70 & 77 & 76 & 72 \\
\hline Child abuse & 206 & 215 & 219 & 215 & 250 \\
\hline Establishment of permanent care for children & 123 & 100 & 93 & 113 & 114 \\
\hline Parents' addiction to gambling & - & - & 1 & 1 & 1 \\
\hline Other reasons & 537 & 610 & 590 & 585 & 537 \\
\hline Total number of children & 25483 & 24222 & 23335 & 22073 & 21303 \\
\hline \multicolumn{6}{|l|}{ From this number due to: } \\
\hline Parents' abuse of alcohol and other substances & 14778 & 13431 & 12496 & 11171 & 10237 \\
\hline Lack of parental skills & 8459 & 8477 & 8605 & 8752 & 8861 \\
\hline Establishment of temporary care for children & 273 & 344 & 366 & 329 & 416 \\
\hline Abuse of social welfare benefits & 235 & 186 & 185 & 176 & 187 \\
\hline Child abuse & 463 & 492 & 484 & 463 & 517 \\
\hline Establishment of permanent care for children & 226 & 152 & 127 & 127 & 127 \\
\hline Parents' addiction to gambling & - & - & 1 & 1 & 1 \\
\hline Other reasons & 1049 & 1140 & 1071 & 1054 & 957 \\
\hline
\end{tabular}

Table 3. The distribution of children in social risk families by age groups in 2008-2012.

\begin{tabular}{|l|l|l|l|l|c|}
\cline { 2 - 6 } \multicolumn{1}{c|}{} & $\mathbf{2 0 0 8}$ & $\mathbf{2 0 0 9}$ & $\mathbf{2 0 1 0}$ & $\mathbf{2 0 1 1}$ & $\mathbf{2 0 1 2}$ \\
\hline Total & $\mathbf{2 5 4 8 3}$ & $\mathbf{2 4 ~ 2 2 2}$ & $\mathbf{2 3 ~ 3 3 5}$ & $\mathbf{2 2 ~ 0 7 3}$ & $\mathbf{2 1 ~ 3 0 3}$ \\
\hline Male & 13375 & 12744 & 12249 & 11578 & 11222 \\
\hline Female & 12108 & 11478 & 11086 & 10495 & 10081 \\
\hline \multicolumn{5}{|c|}{ Age groups } \\
\hline $0-3$ & 3194 & 3084 & 2933 & 2730 & 2714 \\
\hline $4-6$ & 4322 & 3943 & 3735 & 3273 & 3069 \\
\hline $7-9$ & 5022 & 4756 & 4447 & 4200 & 3984 \\
\hline $10-14$ & 7822 & 7760 & 7887 & 7819 & 7513 \\
\hline $15-17$ & 5123 & 4679 & 4333 & 4051 & 4023 \\
\hline
\end{tabular}

There were 11, 222 boys and 10,081 girls from social risk families in Lithuania in 2012 (Table 3). The majority of these children were in the age groups of 10-14 (7513), and 15-17 (4023), while the least children in social risk families were in the age group of 0-3 years (2714) [26-29].

Some authors emphasise that the family is the primary cell and nuclear of society - which is greatly responsible for the future of the country and nation. However, according to the data of The Ministry of Social Security and Labour, 4.4 percent of total population of children in Lithuania are the children from social risk families $[19,25]$. This can have a very negative impact on modern society of Lithuania as social risk families, or if to be more precise - the members of these families, may develop maladjusted self concepts which are linked with the number of negative emotional and behavioural difficulties, distorted image of common values and general make distrustful of other people and society, insecure population [19, 22, 25]. 
Many social risk factors predetermine the incongruence between social risk populations and the society - it may be a poor physical and social environment, moral values decline, inability to adapt to the changing conditions of society. It is worth to take into account that the society is changing and the majority of disadvantaged families are concentrated in rural areas, which used to be a base of traditional agricultural society. The number of children growing in these families is decreasing in recent years, but this is largely caused by migration and declining birth rates tendencies.

\section{Conclusions}

1. According to the scientific findings and legal documents, social risk family can be characterized as the family where at least one of parents, due to the negative behaviour or negative social or economic characteristics existing within the community does not perform or insufficiently performs social role and function delegated to the family.

2. Very often the reasons influencing family's attribution to social risk group are interdependent, resulting in reinforcement of the existing ones or influencing the emergence of the new ones. The needs of the children living within such families are not fully met or are not met at all, the socialization is impaired - for these reasons the children of social risk families are facing a variety of social, physical, psychological problems.

3. The social risk families in Lithuania are rather more concentrated in rural than urban areas. The number of children in these families has decreased over the recent years, but this is largely caused by migration and declining birth rate, as the overall number of social risk families and the number of children at risk in relation to the total number of children has remained the same. The majority of the children are growing in social risk families that are assigned to the register due to alcohol and substance abuse.

\section{References}

[1] Lietuvos Respublikos Statistikos departamentas, Lietuvos vaikai, Socialinė apsauga, Available at: http://web.stat.gov.1t/lt/pages/view/?id=1878

[2] Lietuvos Respublikos Statistikos departamentas, Gimusieji ir natūrali gyventoju kaita Available at: http://web.stat.gov.1t/lt/pages/view/?id=2422

[3] G. Kondrotaite, Sociologija. Filosofija 4, 55-60 (2006)

[4] L. Žalimienè, Skurdo subkultūros ypatumai (Socialinio darbo aspektas) (2004)

[5] Z. Bajorūnas, Šeimos edukologija (1997)

[6] V. Gudžinskienè, R. Gedminienè, Socialinis ugdymas 27(16), 19-31 (2011)

[7] V. Gudžinskienè, A. Railienè, Acta Paedagogica Vilnensia 29, 91-72 (2012)

[8] R. Augutavičius, Ž. Barkauskaitė Lukšienè, V. Gudžinskienè, Outlines of Social Innovations in Lithuania (European Scientific Institute, Kocani, Republic of Macedonia (2013)

[9] Vaiko gerovès plètros 2013-2020m. strategija, Nr. 1-1225 (2013), Available at: https://www.vilnius.1t/vaktai2011/Defaultlite.aspx?Id=3\&DocId= 30224601

[10] Paslaugos socialinès rizikos šeimoms. Available at: http://www.panspc.1t/2-3.htm;

[11] Socialinès rizikos šeima. Available at: http://www.vaikoteises.lt/lt/vaiko_ teisiu_apsauga/socialines_rizikos_seima

[12] Socialinès rizikos šeimu, auginančiu vaikus, irašymo i apskaita, išbraukimo iš apskaitos tvarka. Available at: http://www . joniskis.lt/Veiklos-sritys/Vaiko- 
teisiu-apsauga/Socialines-rizikos-seimu-auginanciu-vaikus-irasymoi-apskaita-isbraukimo-is-apskaitos-tvarka

[13] Socialinès rizikos šeimos metu pabaigoje. Požymiai: administracinè teritorija. Available at: http://db1.stat.gov.lt/statbank/selectvarval/saveselections . asp?MainTable=M3160902\&PLanguage $=0 \& \mathrm{TableStyle}=\&$ Buttons $=\& P X S I$ $\mathrm{d}=6558 \& \mathrm{IQY}=\& \mathrm{TC}=\& \mathrm{ST}=\mathrm{ST} \& \mathrm{rvar} 0=\& \operatorname{var} 1=$ \&rvar $2=\& \mathrm{rvar} 3=\& r \operatorname{var} 4=\& \mathrm{rvar} 5=\& \mathrm{rv}$ $\operatorname{ar} 6=\& r \operatorname{var} 7=\& r \operatorname{var} 8=\& r \operatorname{var} 9=\& r \operatorname{var} 10=\& \operatorname{var} 11=$ = $\operatorname{var} 12=\& r \operatorname{var} 13=\& r \operatorname{var} 14=$

[14] E. Masiliauskienė, V. Griškutė, Mokytojụ ugdymas 14(1), 138-155 (2010)

[15] Lietuvos Respublikos išmokų vaikams įstatymas, Valstybės žinos (1994) Nr. 89-1706

[16] Lietuvos Respublikos Seimo nutarimas 2008 m. birželio 3 d. Nr. X-1569 “Dèl Lietuvos Respublikos socialinès apsaugos ir darbo ministerijos šeimos politikos teisès akto patvirtinimo"

[17] Lietuvos Respublikos socialiniụ paslaugų istatymas, Valstybès žinios (2006) Nr. 17589

[18] Lietuvos Respublikos socialinès apsaugos ir darbo ministro $2003 \mathrm{~m}$. gruodžio 17 d. isakymas Nr. A1-207 "Dèl darbo su socialinėmis rizikos šeimomis metodiniu rekomendacijų patvirtinimo"

[19] J. Guščinskienè, G. Kondrotaitè, Socialinis darbas 6(1), Available at: http://www . mruni.eu/lt/mokslo_darbai/sd/archyvas/dwn.php?id=274449 (2006)

[20] I. Leliūgienè, Socialinio pedagogo (darbuotojo) žinynas (2003)

[21] Lietuvos gyventojai: struktūra ir demografinè raida, Lietuvos statistikos departamentas [prie Lietuvos Respublikos Vyriausybès], Socialiniụ tyrimụ institutas. Vilnius: Statistikos departamentas (2013)

[22] Lietuvos regioninė politika, Probleminės teritorijos, Available at: http://www.nrp. vrm.1t/index.php?id=169

[23] Lietuvos Respublikos Statistikos departamentas, Socialinès rizikos šeimos metŭ pabaigoje, Available at: http://db1.stat.gov.lt/statbank/default.asp?w= 1280

[24] Lietuvos Respublikos Statistikos departamentas, Lietuvos vaikai Migracija, Available at: http://web.stat.gov.1t/lt/pages/view/?id=1878

[25] Lietuvos Respublikos Statistikos departamentas, Dienos centruose socialines paslaugas gave vaikai, Available at: http://db1.stat.gov.1t/statbank/default. asp? $\mathrm{w}=1280$

[26] Lietuvos Respublikos Statistikos departamentas, Darbuotojai ir savanoriai dienos centruose, Available at: http://db1.stat.gov.lt/statbank/default.asp? $\mathrm{w}=1280$

[27] Paslaugos socialinès rizikos šeimoms (2013), Available at: http://www.panspc. lt/2-3-.htm

[28] Socialinès rizikos šeimų, auginančiu vaikus, irašymo i apskaitą, išbraukimo iš apskaitos tvarka (2012), Available at: http://www.joniskis.lt/Veiklossritys/Vaiko-teisiu-apsauga/Socialines-rizikos-seimu-auginanciuvaikus-irasymo-i-apskaita-isbraukimo-is-apskaitos-tvarka

[29] Socialinès rizikos šeima (2013), Available at: http://www.vaikoteises.lt/ lt/vaiko_teisiu_apsauga/socialines_rizikos_seima/ 